UDC 378:334.02

http://doi.org/10.21272/mmi.2019.1-04

JEL Classification: M36, M37

Syed Ali Abbas,

Ph.D., Turiba University, Latvia

University of Engineering \& Technology Lahore, Pakistan

\title{
BRAND LOYALTY OF HIGHER EDUCATION INSTITUTIONS
}

Abstract. There was a time when branding was limited to FMCG and mass manufacturers, but recent times have seen the importance of marketing and brand management of novel sectors like education. Considering this scenario, the main aim of the paper is to investigate the impact of brand awareness and service quality of HE/s (Higher Education Institutions); on their credibility, trust and the loyalty in the long run, which can be achieved through brand promotion and provision of valued services. The purpose further extends in making a comparison of the effect of both brand awareness (BA) and service quality (SQ) on HEls' Loyalty. Methodological tools of the research methods are comprised of Quantitative data relying on a validated questionnaire with a sample size of 139. As the object of the research was higher education institutions (HEls), two Government and two Private universities from Lahore (Pakistan) region were selected, which are involved in the aggressive brand promotion and known for the provision of esteemed service quality. The paper presenting the results of empirical analysis depicts that brand awareness and service quality have a significant impact on brand loyalty of educational institutes; thus, making it compulsory to stress on continuous brand management. However, in comparing both independent variables, it's the service quality that contributes more towards brand loyalty in the long run, yet both aspects work side by side and need to be focused. The results of the research can be equally useful for stakeholders encompassing higher education institutions as service providers, students/guardians as consumers or customers, accredited bodies and professional consultancy/marketing firms for informed decision making in their respective domains. As for research limitation, the data was collected from Lahore region which is known as an educational hub, so the results might show variations in less populated regions. Also, the nature of educational institutes l.e. state or private might account for different standpoints to some extent.

Keywords: branding, brand loyalty, brand management, higher education institutions, marketing, service quality.

Introduction. In the era where promoting a brand has become a priority of every industry to flourish and strengthening the brand has become part and parcel of success for long-term growth, the need for proper brand management is no more a surprise. A time when running promotional campaigns and preferring advertisement budgets over quality was limited to FMCGs only has taken the transition to the novel sectors like education, as these institutes are on verge of aggressive promotional campaigns (Amzat, 2016). Institute being big or small, old or new, whether located in Africa or Asia, Europe or America - the focus towards attracting students is a top priority of educational institutes which is maintained through proper brand management. Looks like that gone are the times when quality was considered by customers (students) the only criteria for selecting an educational institute as how well the brand is familiar and established is a key attribute in their decision-making process now. They want their educational institute to be famous or have an awareness in common, so they carry with them a tag of an acclaimed and trusted brand; thus, helping them in job placement as well (Mabkhot et al., 2017). While students and guardians - being customer prefer a renowned brand as their educational institute (Kayombo and Carter, 2016), higher education institutions (HEls) are leaving no stone unturned to cash on this rising trend and making all necessary attempts to brand their institute. The dark side; however, of this promotion orientation could be the fact that quality provider institution which is lacking in promotional run could become unfamiliar. Therefore, it is important for these institutes/universities to consider the aspect of Brand awareness for their respective institutes as well (Chen and Chen, 2014). Having said this all, this discussion is extended to the fact that what is the best combination of both brand awareness and service quality that can

Cite as: Abbas, S. A. (2019). Brand loyalty of Higher Education Institutions. Marketing and Management of Innovations, 1, 46-56. http://doi.org/10.21272/mmi.2019.1-04 
contribute to ultimate brand loyalty of higher education institutions. Because attracting the students through various promotional aspects and apparent claims might help universities in making students as one time consumes, but the need is to find what happens with the loyalty of educational institutes in the long run, and this is actually the research problem.

So, continuing with the loyalty aspect, $\mathrm{HEI}$ makes big claims at the time of admissions. The campaigns are targeted at various needs with the basic focus on providing quality education and achievements of alumni as well (Tas and Ergin, 2012). High promises for job placements and age of institutions are highlighted in general; depending if educational institutions are born decades ago whereas new institutes rely upon slogans like «state of the art» facilities. The quality of service is not only linked with quality staff but the provision of best infrastructure and fulfilment of extracurricular needs of students are the factors these higher education institutions tend to cash on. HEls continue with some true or overrated claims but what happens in the long run and whether these claims form basis for strong brand loyalty is actually the concern in this research; because in the end its the loyal customers which guarantees organization/ firm/ company's success (Drapinska, 2012) and if the firm or company is service provider and that even an educational institution, then things might not go as expected unless it is delivered what was claimed.

In short, continuing with business terminology a company is expected to grow till the time the customer makes the repetitive purchase (Dick and Basu, 1994) and in context of higher education institutions, the repetitiveness of customer's purchase means the education institution is on right track. Though Zehir (et al., 2011) prove the impact of established brand and service quality on building brand loyalty in automobile and other service industries, the need is to analyze the contribution of established and esteemed brand awareness and service quality on brand loyalty of higher education institutions. What can really win customers' trust and what can make them repurchase from the same brand of institutions, is the need of the hour for modern day HEls to survive. These concerns which are raised in this research leads to the following objectives of the study:

- to overview Students', take on their loyalty with current institutes;

- to make a comparison of the effectiveness of both Service Quality and already established Brand awareness in ensuring brand loyalty;

- to analyse the level of student satisfaction with their current HEls.

To make HEls choose the best fit between brand promotional campaigns or quality of services provided for long term brand loyalty.

Literature Review. To build a strong image has always been an important aspect of product and brand management. The more the stronger brand is created, the greater will be the revenue generation both in the short and long term (Kapferer, 2004; Keller 2003). So, the ultimate goal for creating brand value is to come up with the brands that last for decades (Aaker, 1996). As far as consumer behaviour theory is concerned, A brand is defined as a mark that differentiates a branded identity from others, which could be a symbol, slogan, mark, tag line, specific design, colorful pattern or a best possible combination of all of these (Schiffman, Bednall, O'Cass, Paladino and Kanuk). Therefore, the ability to memorize and recall a brand is «brand awareness» (Einwiller, 2001), whereas the limit to which brand is valued by the customers is called brand equity which is interlinked with the brand trust and loyalty. In a one-liner, the greater the loyalty and trust of the brand is developed in the customer's mind the more will be the brand equity. This brand equity can be achieved through quality, product perceived value and its attributes which are valuable for customers. It's the brand value and brand perception which effects on consumer purchasing behaviour, even before the consumer has prior purchase experience (Hoyer and Brown, 2001; Keller, 1993; Stephen, 1993). So, the importance of creating a strong brand value can't be put aside which have direct impact customers' selection procedure, even if they have little or no experience with previous purchase.

Brand awareness is related to the power and familiarity of a brand about which a customer/ consumer is fully aware of. The prior research in the field of brand management has proved it that a more recognized 
or familiar brand gets lot more positive response than a non-familiar one, even if the unknown brand has more quality orientation (Mclnnis et al., 1999). The brand awareness is considered as the first step towards knowledge and attitude of the brand which give an in-depth overview of what the product is all about. As Aaker (1996) believes that brand awareness can be analyzed from three different aspects l.e. recognition, recall, first recall and dominant and he further adds that consumer is simply concerned in remembering the brand name. Also, it is important to mention that creating awareness amongst masses could be an expensive task to do, the expense of which can be compensated if it is done effectively to increase brand equity.

In more philosophical terms, brand recognition/ awareness is all about the recollection of a brand or once a product is rebought. As mentioned above, the brand gives a positive feeling which makes customer realize that a product/ service coming from a particular brand would surely be of high quality as the company has spent a lot on its promotion. Brand recognition has its strong impact on product class that in some cases it proves out to be a wholly solely recognition for product category e.g. «Cola». In this context, the first word striking customer's mind would be «Pepsi» and «Coca Cola». This particular glimpse of recall is called «first recall», and no wonder it's the dream of every brand to recognize itself in the category of first recall. However, one can confirm a positive brand awareness if the product falls amongst the top few brands in this first recall category.

To understand more about the relationship between brand recognition and brand recall, let's have a look over the following chart.

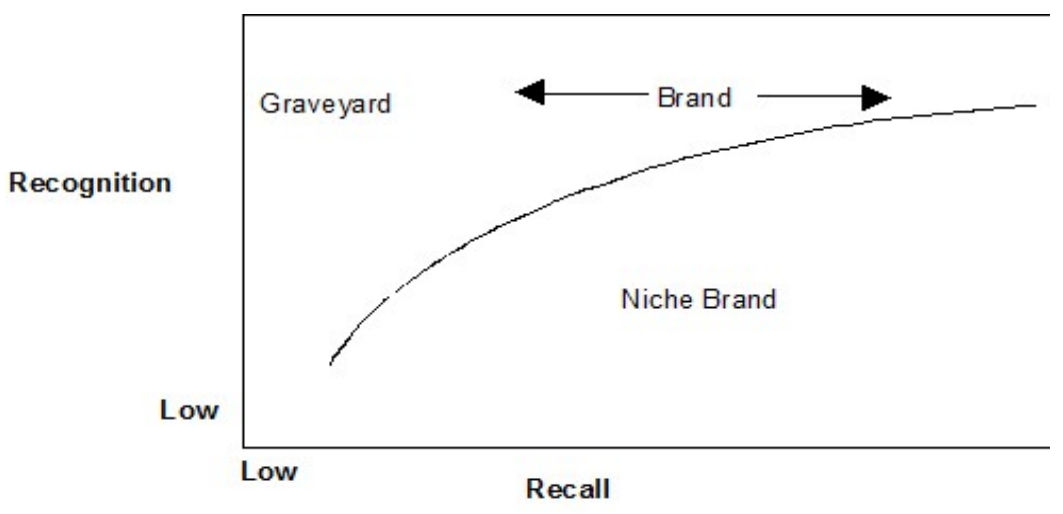

Figure 1. Brand Recognition versus Brand Recall: The Graveyard Model

Sources: (Aaker 1996, p. 15)

It is obvious from the chart above, if the brand falls somewhere in the graveyard portion it means people only recognize when they see it, but don't really recall it in terms of specific product line. Whereas, if the brand lies in the Niche portion, it can clearly be implied that the brand may not be recognized or familiar in masses but is extremely recallable to the specific niche market. The best example, in this case, would be of a «paint brand», which may not be recognizable by many but could be a hot cake in its specific target market for its loyal customers. However, loss of market share and sales can be identified if there observed a movement towards graveyard shown in fig. 1. The above discussion in the context of brand awareness in connection with brand loyalty leads to the formulation of the first hypothesis in this study which is presented below.

$\mathrm{H1}$ : Brand awareness (BA) has a significant impact on brand loyalty (BL). 
Service quality relates to the perceived benefits and customers' perception of the elements of service. It is defined as a global judgement or attitude related to the overall excellence or superiority of the service (Parasuraman et al, 1988). The elements of service quality, especially in the education sector, include interaction quality, physical environment quality and outcome quality. Linking all these elements to HEls, interaction quality accounts for teaching, physical environment refers to infrastructure whereas outcome quality is the results of the service both in terms of admission intakes and further to the results/ scores of the students. (Parasuraman et al, 1998) further defines it as «the degree of discrepancy between customers' normative expectations for the service and their perception of the service performance». Discussing previous studies to analyze customer (student in our case) behavioural intention in the very domain of service setting, Zeithaml et al. (1996) proposed a multi-dimensional framework. This framework gives us the following four dimensions l.e. word of mouth, price sensitivity, purchase intention and complaining behaviour which are considered necessary to maintain effective service by the service provider organizations. This also leads us to fact that HEls should not only rely on spreading their message of quality rather factors like word of mouth etc. discussed in the model above lead to generate brand trust which enhances brand loyalty further. As there exists scarce research regarding the relationship between service quality, brand trust and brand loyalty, especially in the context of higher education Institutions (HEls) the empirical research is almost negligible, the proposed hypothesis in this section could manifold valuable findings. So, the hypothesis concerning service quality in this study is proposed as:

$\mathrm{H} 2$ : Service quality (SQ) has a significant impact on Brand Loyalty (BL)

Methodology and research methods. The research framework in this study is presented below as fig. 2 below. This framework is comprised of independent variables as Brand Awareness (BA) and Service quality $(\mathrm{SQ})$, while Brand Loyalty $(\mathrm{BL})$ is the dependent variable. As this study aims at the comparative analysis of the impact of both predictors individually and exclusively, therefore two path diagrams have been developed separately having the same output/ dependent variable.

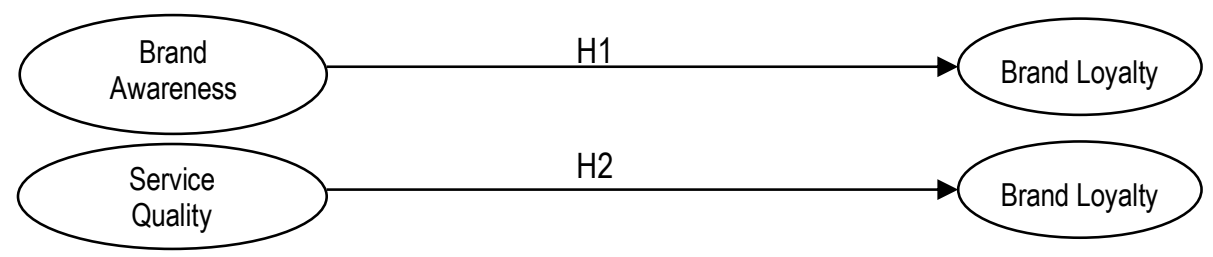

Figure 2. Research Framework

Sources: developed by the author

The constructs in the study were developed by using validated questionnaires having measurement scales adopted from previous studies. Five-point Likert scale with $1=$ Strongly disagree and $5=$ Strongly Agree has been used to measure the constructs. All, items were positively worded with no leading and double barrel questions. Items for measuring brand awareness were adopted from (Aaker, 1996) whereas Items for Service quality (SQ) were taken from previous studies (Brady and Cronin, 2001; Parasuraman et al, 1988; Terblanche and Boshoff, 2001). Similarly, the brand loyalty (BL) measures were adapted from multiple sources (Algesheimer et al., 2005; Fullerton, 2005; Heitmann, Lehman and Herrmann, 2007; Hess and Story, 2005; Johnson et al., 2006; Sierra and Mcquity, 2005; Zeithaml et al., 1996).

As discussed in the previous section, the Higher Education Institution (HEls) have been selected as the research context for this study. Data was collected randomly using online forms and in person from Government and Private HEls in Pakistan. These HEls located in the metropolitan and diverse city of Lahore (known as an educational hub) are selected irrespective of their domains in terms of field and course offerings, considering the research at hand comprises about Brand Loyalty due to the existing level 
of Brand Awareness and Service quality which these HEls are providing to their students. The sampling frame consists of 139 respondents; with the response rate of $75 \%$.

Table 1. Gender Statistics

\begin{tabular}{|c|c|c|c|c|c|}
\hline \multicolumn{2}{|c|}{} & Frequency & Percent & Valid Percent & Cumulative Percent \\
\hline \multirow{3}{*}{ Valid } & Female & 69 & 49.6 & 49.6 & 49.6 \\
\cline { 2 - 6 } & Male & 70 & 50.4 & 50.4 & 100.0 \\
\cline { 2 - 6 } & Total & 139 & 100.0 & 100.0 & \\
\hline
\end{tabular}

Sources: developed by the author

The age groups were divided into three categories l.e. «18 to $23 »$, «24 to 28 » and «29 and above». These different age groups are not just for age profiling but are designed to better link the key findings as between 18 to 23 there happen to be the students who have more probability of continuing their studies than other age groups who might be more focused towards job seeking arrangements. So generally, the perception of age groups regarding brand loyalty gets more significance when age group moves in ascending order.

Table 2. Age Profiling

\begin{tabular}{|c|c|c|c|c|c|}
\hline \multicolumn{2}{|c|}{} & Frequency & Percent & Valid Percent & Cumulative Percent \\
\hline \multirow{4}{*}{ Valid } & 18 to 23 & 66 & 47.5 & 47.5 & 47.5 \\
\cline { 2 - 6 } & 24 to 28 & 62 & 44.6 & 44.6 & 92.1 \\
\cline { 2 - 6 } & 29 and above & 11 & 7.9 & 7.9 & 100.0 \\
\cline { 2 - 6 } & Total & 139 & 100.0 & 100.0 & \\
\hline
\end{tabular}

Sources: developed by the author

The education profiling mentioned in the table 3 below with 40\% Bachelor students (respondents) puts a good total for a general significance of responses about brand loyalty, as again these could be the students who can proceed for higher education. Also, with a considerable percentage of $51 \%$ Master students, one can analyze the credibility of responses about satisfaction with service quality at its existing level in HEls, along with minor percentages of post Master studies.

Table 3. Education Profiling

\begin{tabular}{|c|c|c|c|c|c|}
\hline \multicolumn{2}{|c|}{} & Frequency & Per cent & Valid Percent & Cumulative Percent \\
\hline \multirow{4}{*}{ Valid } & Bachelors & 56 & 40.3 & 40.3 & 40.3 \\
\cline { 2 - 6 } & M.Phil & 11 & 7.9 & 7.9 & 48.2 \\
\cline { 2 - 6 } & Masters & 71 & 51.1 & 51.1 & 99.3 \\
\cline { 2 - 6 } & PhD & 1 & .7 & .7 & 100.0 \\
\cline { 2 - 6 } & Total & 139 & 100.0 & 100.0 & \\
\hline
\end{tabular}

Sources: developed by the author

Results. Table 4 shows the descriptive for predictors and outcome variables separately. Mean Value for Brand Awareness with 4 shows familiarity and recognition of brand having a specific image. How this specific awareness that students as customers have about their $\mathrm{HEI}$ and its impact on Brand Awareness will be dealt with in Regression Analysis. The mean values for Service quality lie around somewhat agree to agree with the column, show the acceptable and trusted level of services by students. As the questions asked in this section ranged from quality teaching to customer service $t$ curriculum development, this high mean value is a sigh of relief for study universities though room for improvement is obvious. Seeing at the loyalty value surrounding at «somewhat agree» value of 3 , this finding foresee some interesting leads in 
this research l.e. despite with high means for Brand awareness and Service quality the students' loyalty is a concern for these HEls. That further leads us to analyze the other hidden aspects or the fact that what combination of two (BA and SQ) will take us to enhanced and desired level of loyalty. This demands us to proceed with the next level of analysis having model testing in the next sections.

Table 4. Descriptive Statistics

\begin{tabular}{|c|c|c|c|c|c|}
\hline & $\mathrm{N}$ & Minimum & Maximum & Mean & Std. Deviation \\
\hline BrandAwareness & 139 & 1.00 & 5.00 & 3.9946 & .88796 \\
\hline ServiceQuality & 139 & 1.00 & 5.00 & 3.7007 & .79066 \\
\hline BrandLoyalty & 139 & 1.00 & 5.00 & 3.3367 & .89993 \\
\hline Valid N (listwise) & 139 & & & & \\
\hline
\end{tabular}

Sources: developed by the author

Correlation Analysis was conducted for study variables. Evident from the table 5. there exists statistically significant $(p=0.00)$ weak positive relation $(r=0.22)$ between brand awareness (predictor 1$)$ and brand loyalty (outcome) and strong positive relation $(r=0.51)$ with significance $(p=0,00)$ between service quality (predictor 2) and brand loyalty. Also, the moderate positive relation between independent variables $(0.43)$ ferret out the collinearity issues. The computation of correlation makes clear extractions that the relation between brand awareness and brand loyalty is rather weaker as compared to the relationship between service quality and brand loyalty.

Table 5. Correlation

\begin{tabular}{|c|c|c|c|c|}
\hline & & BrandAwareness & ServiceQuality & BrandLoyalty \\
\hline \multirow{3}{*}{ BrandAwareness } & Pearson Correlation & 1 & $.433^{* *}$ & $.227^{\star *}$ \\
\hline & Sig. (2-tailed) & & .000 & .007 \\
\hline & $\mathrm{N}$ & 139 & 139 & 139 \\
\hline \multirow{3}{*}{ ServiceQuality } & Pearson Correlation & $.433^{* *}$ & 1 & $.517^{\star \star}$ \\
\hline & Sig. (2-tailed) & .000 & & .000 \\
\hline & $\mathrm{N}$ & 139 & 139 & 139 \\
\hline \multirow{3}{*}{ BrandLoyalty } & Pearson Correlation & $.227^{* *}$ & $.517^{* *}$ & 1 \\
\hline & Sig. (2-tailed) & .007 & .000 & \\
\hline & $\mathrm{N}$ & 139 & 139 & 139 \\
\hline
\end{tabular}

Sources: developed by the author

Correlation Analysis was conducted for study variables. Evident from the table 5. there exists statistically significant $(p=0.00)$ weak positive relation $(r=0.22)$ between brand awareness (predictor 1$)$ and brand loyalty (outcome) and strong positive relation $(r=0.51)$ with significance $(p=0,00)$ between service quality (predictor 2 ) and brand loyalty. Also, the moderate positive relation between independent variables $(0.43)$ ferret out the collinearity issues. The computation of correlation makes clear extractions that the relation between brand awareness and brand loyalty is rather weaker as compared to the relationship between service quality and brand loyalty.

Regression Analysis was applied via SPSS independently for both hypotheses. The reason for independent analysis accounts for the independence of results so comparable and exclusive effect of both variables (service quality and brand awareness) can be judged separately instead of analyzing their mutual contribution on the outcome variable. So, BA and $S Q$ were independent whereas $B L$ was treated as a dependent variable. Let's deal with the first hypothesis:

$\mathrm{H} 1$ : Brand awareness $(B A)$ has a significant impact on brand loyalty $(B L)$. 
H0: Brand awareness $(B A)$ doesn't have a significant impact on brand loyalty $(B L)$

The regression model (table 6-8) proves out to be significant $(F=7.4, R 2=.0 .051, p=0.00)$. As per regression analysis $(p<0.05, b=0.22)$ brand awareness has a significant positive impact on brand loyalty, so the first hypothesis $\mathrm{H} 1$ in the study is supported and null is rejected. Now let's have a look over the second hypothesis of the study.

Table 6. Regression Model for Hypothesis 1

\begin{tabular}{|c|c|c|c|c|c|c|c|c|c|c|}
\hline \multirow[b]{3}{*}{ Model } & \multirow[b]{3}{*}{$\mathrm{R}$} & \multirow{3}{*}{$\begin{array}{c}\mathrm{R} \\
\text { Square }\end{array}$} & \multirow{3}{*}{$\begin{array}{l}\text { Adjusted R } \\
\text { Square }\end{array}$} & \multirow{3}{*}{$\begin{array}{l}\text { Std. Error of } \\
\text { the Estimate }\end{array}$} & \multirow{2}{*}{\multicolumn{5}{|c|}{ Change Statistics }} & \multirow{3}{*}{$\begin{array}{l}\text { Durbin- } \\
\text { Watson }\end{array}$} \\
\hline & & & & & & & & & & \\
\hline & & & & & $\begin{array}{c}\text { R Square } \\
\text { Change }\end{array}$ & $\begin{array}{c}\mathrm{F} \\
\text { Change }\end{array}$ & $\mathrm{df1}$ & $\mathrm{df} 2$ & $\begin{array}{c}\text { Sig. F } \\
\text { Change }\end{array}$ & \\
\hline 1 & $.227^{\mathrm{a}}$ & .051 & .044 & .87974 & .051 & 7.409 & 1 & 137 & .007 & 1.970 \\
\hline \multicolumn{11}{|c|}{ a. Predictors: (Constant), BrandAwareness } \\
\hline \multicolumn{11}{|c|}{ b. Dependent Variable: BrandLoyalty } \\
\hline
\end{tabular}

Sources: developed by the author

Table 7. ANOVA for Hypothesis 1

\begin{tabular}{|c|c|c|c|c|c|c|}
\hline \multicolumn{2}{|c|}{ Model } & Sum of Squares & $\mathrm{df}$ & Mean Square & $\mathrm{F}$ & Sig. \\
\hline \multirow{3}{*}{1} & Regression & 5.734 & 1 & 5.734 & 7.409 & $.007^{\mathrm{b}}$ \\
\cline { 2 - 7 } & Residual & 106.029 & 137 & .774 & & \\
\cline { 2 - 7 } & Total & 111.763 & 138 & & \\
\hline \multicolumn{7}{|c|}{ a. Dependent Variable: BrandLoyalty } \\
\hline
\end{tabular}

Sources: developed by the author

Table 8. Hypothesis 1 Coefficients

\begin{tabular}{|c|c|c|c|c|c|c|c|c|c|c|}
\hline \multirow{2}{*}{\multicolumn{2}{|c|}{ Model }} & \multicolumn{2}{|c|}{$\begin{array}{c}\text { Unstandardized } \\
\text { Coefficients }\end{array}$} & \multirow{2}{*}{\begin{tabular}{|c|c}
$\begin{array}{c}\text { Standardized } \\
\text { Coefficients }\end{array}$ \\
Beta
\end{tabular}} & \multirow{2}{*}{$\mathrm{t}$} & \multirow{2}{*}{ Sig. } & \multicolumn{2}{|c|}{$\begin{array}{c}95.0 \% \text { Confidence } \\
\text { Interval for B }\end{array}$} & \multicolumn{2}{|c|}{$\begin{array}{l}\text { Collinearity } \\
\text { Statistics }\end{array}$} \\
\hline & & B & Std. Error & & & & $\begin{array}{l}\text { Lower } \\
\text { Bound }\end{array}$ & $\begin{array}{l}\text { Upper } \\
\text { Bound }\end{array}$ & Tolerance & VIF \\
\hline \multirow[b]{2}{*}{1} & (Constant) & 2.420 & .345 & & 7.01 & .000 & 1.737 & 3.102 & & \\
\hline & BrandAwareness & 230 & .084 & .227 & 2.72 & .007 & .063 & .396 & 1.000 & 1.000 \\
\hline
\end{tabular}

Sources: developed by the author

The results of checking $\mathrm{H} 2$ (Service quality (SQ) has the significant impact on Brand Loyalty (BL) and $\mathrm{HO}$ (Service quality (SQ) doesn't have the significant impact on Brand Loyalty (BL) are presented in Table 9-11.

Table 9. Regression Model for Hypothesis 2

\begin{tabular}{|c|c|c|c|c|c|c|c|c|c|c|}
\hline \multirow{3}{*}{ Model } & \multirow{3}{*}{$\mathrm{R}$} & \multirow{3}{*}{$\begin{array}{c}\mathrm{R} \\
\text { Square }\end{array}$} & \multirow{3}{*}{$\begin{array}{l}\text { Adjusted R } \\
\text { Square }\end{array}$} & \multirow{3}{*}{$\begin{array}{c}\text { Std. Error of } \\
\text { the } \\
\text { Estimate }\end{array}$} & \multirow{2}{*}{\multicolumn{5}{|c|}{ Change Statistics }} & \multirow{3}{*}{$\begin{array}{l}\text { Durbin- } \\
\text { Watson }\end{array}$} \\
\hline & & & & & & & & & & \\
\hline & & & & & $\begin{array}{l}\text { R Square } \\
\text { Change }\end{array}$ & $\begin{array}{c}\mathrm{F} \\
\text { Change }\end{array}$ & df1 & df2 & $\begin{array}{l}\text { Sig. F } \\
\text { Change }\end{array}$ & \\
\hline 1 & $.517^{\mathrm{a}}$ & .268 & .262 & .77291 & .268 & 50.087 & 1 & 137 & .000 & 1.737 \\
\hline \multicolumn{11}{|c|}{ a. Predictors: (Constant), ServiceQuality } \\
\hline \multicolumn{11}{|c|}{ b. Dependent Variable: BrandLoyalty } \\
\hline
\end{tabular}

Sources: developed by the author 
Table 10. ANOVA for Hypothesis 2

\begin{tabular}{|c|c|c|c|c|c|c|}
\hline \multicolumn{2}{|c|}{ Model } & Sum of Squares & Df & Mean Square & F & Sig. \\
\hline \multirow{3}{*}{1} & Regression & 29.921 & 1 & 29.921 & 50.087 & $.000^{\mathrm{b}}$ \\
\cline { 2 - 7 } & Residual & 81.842 & 137 & .597 & & \\
\cline { 2 - 7 } & Total & 111.763 & 138 & & \\
\hline \multicolumn{7}{|c|}{ a. Dependent Variable: BrandLoyalty } \\
\hline \multicolumn{7}{|c|}{ b. Predictors: (Constant), ServiceQuality } \\
\hline
\end{tabular}

Sources: developed by the author

Table 11. Hypothesis 2 Coefficients

\begin{tabular}{|c|c|c|c|c|c|c|c|c|c|c|}
\hline & \multirow{2}{*}{ Model } & \multicolumn{2}{|c|}{$\begin{array}{l}\text { Unstandardized } \\
\text { Coefficients }\end{array}$} & \multirow{2}{*}{\begin{tabular}{|c|}
$\begin{array}{c}\text { Standardized } \\
\text { Coefficients }\end{array}$ \\
Beta
\end{tabular}} & \multirow{2}{*}{$t$} & \multirow{2}{*}{ Sig. } & \multicolumn{2}{|c|}{$\begin{array}{l}95.0 \% \text { Confidence } \\
\text { Interval for B }\end{array}$} & \multicolumn{2}{|c|}{$\begin{array}{l}\text { Collinearity } \\
\text { Statistics }\end{array}$} \\
\hline & & B & Std. Error & & & & $\begin{array}{l}\text { Lower } \\
\text { Bound }\end{array}$ & $\begin{array}{l}\text { Upper } \\
\text { Bound }\end{array}$ & Tolerance & VIF \\
\hline \multirow{2}{*}{1} & (Constant) & 1.157 & .315 & & 3.67 & .000 & .535 & 1.780 & & \\
\hline & ServiceQuality & .589 & .083 & .517 & 7.07 & .000 & .424 & .753 & 1.000 & 1.000 \\
\hline & \multicolumn{10}{|c|}{ a. Dependent Variable: BrandLoyalty } \\
\hline
\end{tabular}

Sources: developed by the author

The regression model (table 9-11) proves out to be significant $(F=50.4, R 2=0.26, p=0.00)$. $\mathrm{H} 2$ is also supported as there exists a significant positive impact of service quality on brand loyalty $(p<0.05, b=$ 0.51 ), hence null is rejected. The beta coefficients values make it easier for readers that in comparison it's the service quality that contributes more towards brand loyalty than brand awareness when studied exclusively.

Conclusions. Though in comparison the quality of services contributes more towards loyalty or longterm retention yet the importance of awareness through promotion is significant in its own domain and in varying situations it might be needed the most, even for a specific time period. This study shows that brand awareness is positively and significantly related to brand loyalty $(p<0.05, b=0.22)$ and this result is the same as findings of Aaker and Keller (1990). While, Mabkhot, Shaari, \& Salleh (2017) discusses brand loyalty as an outcome of brand image in the automobile sector, this study takes another dimension of loyalty as an outcome of brand awareness in the higher education setting, suggesting that HEls should connect itself to all the means contributing towards its brand building. And in that context, provision of quality services and promotional attempts become part of this established brand awareness that aims at cashing future awareness and brand loyalty of students. According to Wel (et al.2011) when the customer makes a purchase, they become more aware of the source channel and are more sensitive to the information on brands, therefore credibility of sources and selecting right channels are vital for brand awareness.

While not forgetting that loyalty in the education sector is about readmissions and spreading positive word of mouth by students about their current or attended $\mathrm{HEI}$, the role of service quality can't be neglected for consistent and long-term retention of students as customers. The results in this study that service quality (SQ) effects brand loyalty (BL) are consistent with that of Zehir (et al., 2011). However, at the same time, this doesn't allow HEls to overlook awareness aspects. The point to make is that this established awareness, which can actually be the outcome of known or delivered services, aggressively marketed CSFs (critical success factors) or even previous placements of alumni etc. has contributed to loyalty but HEls must not need to stop and continue to extend, innovate and reinvent their services, because ultimately it's the current level of quality services which will affect the loyalty in the long run. As previous studies by Dean (et al., 2016), Kayombo and Carter (2016), Aghaz (et al., 2015) throw light on factors 
contributing towards brand image and importance of branding for higher education institutions, this study entails researchers to extend their research to loyalty aspects of Higher Education Institutions, as it's the loyalty that paves way for a brand to be termed as trusted, credible and a brand of generations. According to finding the recommendations and suggestions could be as follows:

The Higher Education institutions should: understand the importance of optimum and efficient educational services for consistent and long-term brand loyalty; comply with respective accreditation authorities both local and internationally; overview students' expectations with modern demands of changing era. This can range from Methodological to technological advancements; use brand promotion to the extent that it corresponds with delivered or prospect delivery of services. Relying wholly solely on existing awareness won't just be enough; allocate a balanced fit of financial resources to the promotion and actual delivery of services.

The customers including students/guardians/ caretakers or the concerned custodians in the decisionmaking process are suggested to: identify institute/ HEI with better understanding about present standing or future of the selected institute; get acquainted with the knowledge of merits and demerits of an accredited $\mathrm{HEl}$; adhere themselves to quality oriented educational providers other than only aggressively marketed; choose an institute with a reputation of industry-academia linkages; propagate authentic and an unbiased word of mouth about their HEI, so that it generates valid awareness about coming lot of students.

As state Councils are directly responsible for accreditation/ licensing of HEls for up to the mark provision of education, these are suggested to: have a constant and periodic check on accredited HEls performance; developing innovative and challenging KPIs (Key Performance Indicators) for HEls for successful accreditations; provide the required support in terms of Grants, Training, R\&D to the HEls for execution of quality services; act as an effective intermediary between state and the institutes to facilitate the needs and wants of both parties; developing effective communication via portals/ cells/ desks with students so that their on-spot queries, feedback and concerns are dealt with accordingly.

Both private and public research organizations, marketing consultancy firms are suggested to the effective use of Brand Loyalty Matrix which can make their work easy in: ranking of HEls and their performance; developing and interpretation of customers' (students etc.) surveys and questionnaires; designing the marketing plans for the Institutes based upon their current standings in the market; making comparative and competitive analysis etc. for their consulted HEl.

\section{References}

Aaker, D. A., \& Keller, K. L. (1990). Consumer evaluations of brand extensions. Journal of Marketing, 54(1), $27-42$.

Aaker, David A. (1996), «Measuring Brand Equity Across Products and Markets», California Management Review, 38 (Spring), 102-20.

Aghaz, A., Hashemi, A., \& Sharifi Atashgah, M. S. (2015). Factors contributing to university image: the postgraduate students' points of view. Journal of Marketing for Higher Education, 25(1), 104-126.

Algesheimer, Rene, Dholakia, Uptal M., Herrmann, Andreas (2005), «The Social Influence of Brand Community; Evidence from European Car Clubs», Journal of Marketing, Vol.69, p.19-34.

Amzat, I. H. (2016). Branding Higher Education Institutions: What It Takes to be Branded. Fast forwarding Higher Education Institutions for Global Challenges (pp. 147-162).

Brady K. Michael \& Jr. J. Joseph Cronin, (2001), «Some New Thoughts on Conceptualizing Perceived Service Quality: A Hierarchical Approach», Journal of Marketing Vol.65 (July 2001), p. 34-39.

Chen, C.-F., \& Chen, C.-T. (2014). The effect of higher education brand images on Satisfaction and lifetime value from students' viewpoint. Anthropologist, 17(1), 137-145

Dean, D., Arroyo-Gamez, R. E., Punjaisri, K., \& Pich, C. (2016). Internal brand co-creation: The experiential brand meaning cycle in higher education. Journal of Business Research, 69(8), 3041-3048.

Dick, Alan S. and Kunal Basu (1994), "Customer Loyalty: Toward an Integrated Conceptual Framework», Journal of the Academy of Marketing Science, 22 (Spring), 99-113. 
Einwiller, S. (2001), «The significance of reputation and brand for creating trust in the different stages of a relationship between an online vendor and its customers», Proceedings of Eighth Research Symposium on Emerging Electronic Markets, Maastricht, The Netherlands.

Fullerton Gordon, (2005), «The Impact of Brand Commitment On Loyalty to Retail Service Brands», Canadian Journal of Administratiand Sciences 22(2), 97-110.

Heitmann, Mark, Lehman, Donald R., and Herrmann, Andreas, 2007, Choice Goal Attainmentand Decisionand Consumption Satisfaction, Journal of Marketing Research, Vol.Xliv, May 2007, S.234-250.

Hess Jeff, Story John, (2005), «Trust-Based Commitment: Multidimensional Consumer-Brand Relationships», Journal of Consumer Marketing 22/6 313-322.

Johnson Michael D., Herrmann Andreas \& Huber Frank, (2006), The Evolution of Loyalty Intentions, Journal of Marketing Vol.70, S.122-132.

Kapferer, J.-N. (2004), The New Strategic Brand Management: Creating and Sustaining Brand Equity Long Term, Kogan Page, London.

Kayombo, K. M., \& Carter, S. (2016). Understanding Student Preferences for University Choice in Zambia.6(3).

Keller, K.L. (1993), «Conceptualizing, measuring, and managing customer-based brand equity», Journal of Marketing, Vol. 57, pp. 1-22.

Sierra Jeremy and Mcquity Shaun, (2005), «Service Providers and Customers: Social Exchange Theory and Service Loyalty», Journal of Services Marketing 19/6 392-400.

Drapińska, A. (2012). A concept of student relationship management in higher education. Prace Instytutu Lotnictwa 6 (227), 35-49.

Hoyer, W.D. and Brown, S.P. (2001), «Effects of brand awareness on choice for a common, repeat-purchase product», Journal of Consumer Research, Vol. 17, pp. 141-8.

Macinnis, D. J., Shapiro, S., \& Mani, G. (1999). Enhancing Brand Awareness Through Brand Symbols. Advances in Consumer Research, 26(1), 601-608.

Mabkhot, H. A., Shaari, H., \& Salleh, S. M. (2017). The Influence of Brand Image and Brand Personality on Brand Loyalty, Mediating by Brand Trust: An Empirical Study. Jurnal Pengurusan, 50, 1-18.

Parasuraman, A., Zeithaml, V. A., \& Berry, L. L. (1988). SERVQUAL: A multiple-item scale for measuring consumer perceptions of service quality. Journal of Retailing, 64(1), 12-40.

Schiffman, L., Bednall, D., O'Cass, A., Paladino, A. and Kanuk, L. (2005), Consumer Behavior, 3rd ed., Pearson Education Australia, Sydney.

Stephen, J.S. (1993), «Understanding brand awareness: let me give you a clue!», Advances in Consumer Research, Vol.

20, pp. 383-8.

Tas, A., \& Ergin, E. A. (2012). Key factors for student recruitment: The issue of university

branding. International Business Research, 5(10), 146.

Terblanche, N.S. and Boshoff, C., (2001), "Measuring Customer Satisfaction With The Controllable Elements of The In-

Store Shopping Experience", S.Afr.Bus.Manage., 32, p.8-18

Temple, P., Shattock, M. "Branding in Higher Education-Exloring an Emerging Phenomenon" EAIR Research Series,

Policy and Practice in Higher Education, pp 73-79, 2007.

Wel, C.A.B.C., Alam, S. S., \& Nor, S.M. (2011). Factors Affecting Brand Loyalty: An Empirical Study in Malaysia. Australian Journal of Basic and Applied Sciences, 5(12), 777-783.

Zehir, C., Şahin, A., Kitapçı, H., \&Özşahin, M. «The Effects of Brand Communication and Service Quality in Building Brand Loyalty Through Brand Trust; The Empirical Research On Global Brands», ProcediaSocial and Behavioral Sciences, 24, 12181231(2011).

Zeithaml, V. A., Berry, L. L., \& Parasuraman, A. (1996). The Behavioral Consequences of Service Quality. Journal of Marketing, 60(2), 31-46.

C. A. Аббас, Ph.D., Університет Туріба (Латвія), Університет інженерії та технологій Лахора (Пакистан).

Лояльність до бренду закладів вищої освіти

Сучасні тенденції функціонування та розвитку світової економіки обумовлюють використання та поширення теорій маркетингу та бренд-менеджменту не лише для популяризації товарів повсякденного споживання та масового виробництва, а й впровадження їх у діяльність закладів вищої освіти (ЗВО). У зв'язку з цим, головною метою даного дослідження $є$ аналіз впливу рівня популярності бренду та якості надання послуг ЗВО на його репутацію (імідж), рівень довіри до ЗВО та лояльність споживачів до бренду ЗВО у довгостроковій перспективі. Автором наголошено, що просування бренду ЗВО забезпечує підтримку попиту на його послуги. Відповідно до мети дослідження автором проведено порівняльний аналіз ступеня впливу рівня популярності бренду і якості послуг на лояльність споживачів до бренду ЗВО. У рамках даного дослідження вибірку даних сформовано на основі анкетування 139 респондентів. Об'єктом дослідження обрано зВо, зокрема, два державних та два приватних університети регіону Лахор (Пакистан), які використовують агресивний метод 
просування бренду та надають високоякісні освітні послуги. Отримані результати емпіричного аналізу свідчать про статистично значимий вплив рівня популярності бренду та якості послуг на лояльність споживачів до бренду ЗВО. Так, автор дослідження наголошує на необхідності постійного використання принципів бренд-менеджменту у системі управління $3 В 0$. у статті зазначено, що порівнюючи ступені впливу незалежних змінних між собою, якість послуг у більшій мірі сприяє підвищенню лояльності споживачів до бренду ЗВО у довгостроковій перспективі. Автор зазначає, що у процесі прийняття обгрунтованих рішень у межах відповідних компетенцій, результати дослідження можуть бути корисними для представників широкого кола стейкхолдерів 3ВО: студентів, абітурієнтів, акредитованих освітніх організацій, професійних консалтингових компаній/маркетингових фірм та ін. Оскільки у рамках даного дослідження проаналізовано дані регіону Лахор, який є освітнім центром Пакистану, то автор припускає, що при аналізі менш населених регіонів у результатах дослідження можуть простежуватись певні відмінності. Окрім цього, форма власності $3 В 0$ (державна чи приватна) в певній мірі може сприяти виникненню відмінностей у результатах дослідження.

Ключові слова: брендинг, лояльність бренду, заклади вищої освіти, маркетинг, якість послуг.

Manuscript received: 29.11 .2018

(c) The author(s) 2019. This article is published with open access at Sumy State University. 